Article

\title{
Rumors of Our Demise Have Been Greatly Exaggerated: Archaeological Perspectives on Culture and Sustainability
}

\author{
Cameron B. Wesson \\ Department of Sociology and Anthropology, Lehigh University, 681 Taylor Street, Bethlehem, \\ PA 18015, USA; E-Mail: caw411@Lehigh.edu; Tel.: +1-610-758-5319; Fax: +1-610-758-6552
}

Received: 5 November 2012; in revised form: 14 December 2012 / Accepted: 17 December 2012 / Published: 7 January 2013

\begin{abstract}
Predictions of the imminent demise of Indigenous cultures have circulated among Western intellectuals for more than two hundred years. Capitalism, Christianity, and Western civilization were thought by 19th century scholars to be on the verge of eradicating global cultural variation. Contemporary scholars have revived these views, suggesting that not only were Indigenous cultures about to succumb to Western hegemony, these forces were poised to bring about the end of history itself. What unites these perspectives are an ideology stressing asymmetrical power relations between the West and Indigenous cultures, and the proposition that only Western intervention is capable of rescuing Indigeneity. This paper examines the current crisis of Indigenous cultural sustainability, arguing that the epistemology informing many of these perspectives remain largely unchanged from their 19th century precursors. Citing case studies in archaeology and cultural heritage management, I suggest a ground-up approach to cultural sustainability in which Western institutions and individuals serve only the expressed desires and at the invitation of Indigenous peoples. Such restraint represents both recognition of Indigenous sovereignty regarding all cultural preservation efforts, as well as the dynamic, ever-changing nature of culture itself.
\end{abstract}

Keywords: culture; sustainability; epistemology; archaeology; culture heritage

\section{Introduction}

Since the discipline's founding in the waning days of the 19th century, American anthropology has possessed several unique characteristics. Reflecting the principal intellectual concerns of its most influential initial proponent, Franz Boas, the first generation of American anthropologists was 
concerned with studies of the various Indigenous peoples of the Americas (hereafter referred to as Amerinds) [1,2]. These groups were of particular importance to Boasians because they believed Amerind cultures faced imminent extinction due to the pervasiveness of normative American culture [2,3]. The largely unspoken epistemology informing these views was a belief in the superior qualities-both material and immaterial-of Western culture. The eventual assimilation of Amerind peoples into the dominant Americans cultural mainstream was regarded as inevitable. Thus, early American anthropologists formed a phalanx devoted to recording every aspect of Amerind societies before their extinction, including languages, customs, mythologies, physical traits, and excavations of their ancient settlements. Such immersive study led to inevitable parody, with a common joke told among the Navajo suggesting that the average 20th century Navajo family consisted of "a grandmother, mother, father, three children, and an anthropologist." Not coincidentally, this holistic approach was also to result in yet another unique aspect of American anthropology, a four-field approach stressing the importance of Ethnology, Biology, Linguistics, and Archaeology to our understanding of culture.

Although Boasian concern for the imminent extinction of Amerind cultures seems somewhat ethnocentric by contemporary standards, it represented the "cutting edge" of social science research for its time. During an era when most believed Amerind cultures were incapable of providing meaningful insight into the human condition or had been irredeemably altered by four centuries of encroachment by Europeans and Americans, Boas and his students argued many important aspects of Indigenous culture remained to be "salvaged" [2,4]. In addition, Boas was a primary advocate for the controversial view of cultural relativism, a belief in the inherent equality of all human societies. It thus seems odd that someone so committed to the notion of cultural understanding in a non-judgmental framework would presuppose that the Indigenous cultures he studied would be overwhelmed inescapably by the very culture of which he was a part.

Fortunately, predictions of mass cultural extinction among Amerind groups proved wrong. That is not to say that the more than 500 years of cultural interaction between themselves, Europeans, and Americans have not witnessed dramatic change in Amerind cultures, nor is it to suggest that contemporary concerns for the cultural sustainability of these same groups are not well founded. What is clear, however, is that Boasians underestimated the resilient nature of culture. These early anthropologists commonly employed equilibrium models where culture was conceived as static and deterministic, controlling the actions, beliefs, and dispositions of individuals [5]. For Boasians, culture was a distinct whole, a unity encompassing all forms of social knowledge and practice. Thus, these scholars stressed homeostatic views of cultures, where change came about through the application of external forces rather than internal evolution. Change was therefore anathema to the system, with too much change representing the death—or extinction—of an entire cultural system [2,6].

Contemporary anthropology largely has rejected these views, but for many non-anthropologists, these homeostatic, normative views of culture continue to predominate conceptions of both Amerind and global Indigenous cultures. This is certainly the case in much of the recent literature on cultural sustainability generated within the ecological community ([7,8, see critiques in [9-12]). Anthropologists no longer conceive of culture as a discrete whole in complete unity with itself, but as a dynamic, interactive network of contingencies and possibilities. Instead of proscribing action, culture offers innumerable opportunities for variation, creativity, dialectical self-evaluation, and alteration [13]. 
Rather than dooming the unique ways of life of Amerind groups to inevitable extinction, culture's inherent flexibility allowed groups to survive massive depopulation due to European-introduced diseases (estimated as high as 90\%) [14], dispossession of their ancestral homelands, the removal of their youth from their communities by mandatory government-sponsored reeducation programs, active suppression of their religions and languages, widespread institutional discrimination, and other benevolent attempts to "civilize the savage." Explicit recognition of the inherent self-sustaining capabilities of culture among scholars in the ecological community will result in very different understanding of the processes of culture change, survival, and sustainability.

In this paper I examine the epistemological basis for various programs designed to aid Amerinds and other Indigenous groups in sustaining their cultures against the onslaught of globalization and other forces of change. Although most such efforts are based in good intentions, those advocating these programs frequently build their perspectives of Indigenous cultures on flawed views of what culture is and what culture does. Thus, many of these efforts fail to recognize the inherent ethnocentrism of views equating Indigeneity with a state of nature [15-20]. Such equivalencies are generated and perpetuated both through naiveté of cultural resiliency and intellectual traditions (like that of the Boasians) that seek to maintain cultures at particular historical moments and deny them the possibility of change; resulting in the equivalent of a culture fossilized in amber, maintaining its present form in perpetuity. Not only are these views misguided and theoretically under-informed, they are harmful to the very Indigenous peoples these purport to help because they create - and perpetuate anew-views of Indigenous peoples as passive victims of modernization and globalization.

In addition, Western voices all too frequently seek to speak for Indigenous peoples on a global scale, advancing Western discourses based in cults of scientific expertise while creating a unified, one-size-fits-all caricature of non-Western cultures and peoples [13,21,22]. Such views are certainly popular among Western change-agents when meeting at the United Nations or in other venues exemplifying Western power, but they often prove less convincing to those on the frontlines of Indigenous struggle. After all, if the last five centuries have made anything clear to Amerinds and other Indigenes, it is that when Western actors suggest they are undertaking an action designed to help them, things are probably going to get much worse in the very near future [23-26]. Cases of good intentions gone awry are not confined merely to the activities of the International Monetary Fund, World Bank, or other international development agencies, but plague almost every effort made by Western institutions (and individuals) on behalf of Indigenes lacking adequate consultation.

Finally, I present several case studies from American anthropological archaeology, my particular sub-field, some where the "good intentions" of academic professionals at creating sustainability have resulted in unexpected conflict with Indigenes over the best way to preserve important aspects of culture and local environments. I have also chosen examples from archaeology because it is a "cross-cultural and transhistorical" discipline "with the ability to reflect upon the human condition throughout time and in various places ... [and] contribute to the making of the emerging global society" ([27], p. 217). I suggest that the appropriate role for anthropologists, and every specialist engaged in cultural and ecological sustainability efforts (regardless of academic discipline), is that of advocate, not organizer. Academics are accustomed to being the best-educated, most experienced problem-solver in most professional engagements. Such experience makes it common for us to seek control of sustainability efforts when working with Amerinds and other Indigenes. The accumulated 
evidence of past experience, however, suggests that we must actively resist "volunteering" our expertise when it has not been requested, but serve instead as ready allies and accomplices in Indigenous-generated cultural sustainability efforts.

\section{Defining Culture}

Franz Boas was certainly not the first voice to raise concerns that Amerind and other Indigenous cultures were on the verge of extinction with the dawn of the 20th century [8,28]. The pervasive views of that era stressed the racial and cultural inferiority of non-Western peoples. Such perspectives began with the apparently benign premise that Western Europe had progressed from "savagery" to "civilization" because of inherent intellectual abilities [29]. The answers commonly offered to explain a comparative lack of technological and sociological sophistication on the part on non-Western groups were not so benevolent. Non-Western societies were seen as having failed to progress due to any number of maladaptations, but underlying most of these explanations was an idea that members of these groups lacked the intellectual capabilities necessary to enable cultural progress [30]. Such views were so insidious that even when evidence of Indigenous cultural complexity was discovered, it was explained away using convoluted logics that make absolute mockeries of Occam's razor. Thus, stone-faced pyramids in Central and South America were interpreted not as evidence of Indigenous cultural development, but the result of ancient Egyptians having visited the Americas. Tens of thousands of earthen mounds in North America were not seen as the product of Amerind ingenuity, but that of ancient Israelites, Phoenicians, Welsh sailors, or Atlanteans [31-33]. In Southern Africa, the massive city of Great Zimbabwe was ascribed to the efforts of Phoenicians, Arab traders, King Solomon, and the Queen of Sheba-almost anyone it appears, but the dark-skinned Shona-speaking peoples who inhabited the region at the time of its construction [34].

Although most of these racist, Eurocentric views predated by centuries the establishment of the discipline of Anthropology, Franz Boas, himself a German immigrant to the United States from a prominent Jewish family, invested considerable effort to counter them [10]. His then radical vision was one in which all cultures were equal, with differences in technological complexity not the result of inherent racial abilities, but rather historical accident. These views were to form the basis for Boasian cultural relativism, a hallmark of Anthropological practice that continues to influence the direction of the discipline. Although the prospect of cultural relativism may not appear revolutionary to a modern audience, it is important to remember that this idea was developed amid the same intellectual milieu that produced apologia for European empires as part of “The White Man's Burden" [35,36].

However, despite their relativistic perspectives, Boasian anthropology was itself the product of a particular historical moment. Theirs was an era in which Amerind societies largely had been removed from the eastern half of North America and had experienced tremendous dislocative forces-both culturally and physically. The long-term impacts of these forces were seen as inevitably resulting in the acculturation of Native peoples, where their smaller-scale societies would be swallowed up by the larger, more complex culture of the expanding United States [37]. Thus, the melting pot of America was not designed to blend the cultural attributes of each individual group into an amalgam, but was instead a crucible in which the unique characteristics of various ethnic and cultural groups would be 
forever purged to perpetuate a collective national American culture. For Boasians, this processes demanded immediate salvage ethnography of Amerind cultures.

As stated previously, the widespread and imminent demise of Amerind cultures proposed by Boasians did not occur. Many cultural practices and languages most certainly have been irretrievably lost to the forces we now recognize as part of globalization, but what most interests me in this essay is the way in which the majority of Amerind and Indigenous cultures persisted, despite the accumulated cultural assaults of the past five hundred years of global history. With that said, many would counter immediately by questioning whether 16 th century Cherokees would recognize their 21st century descendants. Would the Kayapo, Hopi, or Ch'orti' Maya? Such questions betray a pervasive - and particularly insidious - Western ontology that demands of Indigenes a litmus test of cultural authenticity to which it does not subject itself [38]. It is common to speak of English, American, Irish, or French cultures without demanding in-depth examinations of the dramatic changes all have undergone since the 17th century, or suggesting these cultures have become extinct. Thus, the concept of change does not appear to be an impediment to general discussions and understandings of culture, unless, apparently, such discussions are applied to Indigenes!

By the 1950s, some American anthropologists began moving beyond the immediacy of data recovery, with a range of theoretical questions brought to bear on the immense data accumulated during the prior decades of field research. During this era, anthropologists came to accept the principle that cultures could - and did-evolve. Primarily led by the pioneering efforts of Leslie White and Julian Steward, American anthropology began to embrace models of culture change. Building upon earlier work by scholars such as Clark Wissler [39-41], White and Steward led a rising wave of mid-Twentieth century American anthropologists embracing the notion that natural environments played tremendously important roles in the process of change $[42,43]$. Steward's field research in the Great Basin led him to formulate the theory of cultural ecology, a perspective built upon the idea that cultures adapt in concert with local natural environments. Rather than a strict environmental determinism, however, Steward's views left room for historical contingency, invention, diffusion, and chance [43]. Steward's views on the culture-nature relationship have become staples of the human ecological literature, with his views apparently having a much larger contemporary following outside the discipline of anthropology than within.

Although anthropology has long maintained the culture concept as one of its disciplinary distinctions, over the past thirty years the concept has crept into almost every facet of the social sciences and humanities. The successful expansion of cultural perspectives outside anthropology is in large part the result of Clifford Geertz's considerable intellectual footprint. Geertz, one of those rare intellects whose impact transcended disciplinary boundaries, famously defined culture in an oblique manner, stating, "Man is an animal suspended in webs of significance he himself has spun. I take culture to be those webs" ([44], p. 5). Geertz provided other, more transparent approximations of his definition of culture, including culture as "... an historically transmitted pattern of meanings embodied in symbols, a system of inherited conceptions expressed in symbolic forms by means of which men communicate, perpetuate, and develop their knowledge about and attitudes toward life" ([44], p. 89). Such views place Geertzian anthropology squarely within a cognitive framework, where culture is defined through the various interpretations of symbols and processes of meaning creation rather than a script proscribing ideologies and behaviors. These views represent a challenge to older views of 
culture, like those advocated by Boas, Edward Burnett Tyler, Bronislaw Malinowski, and Claude Levi-Strauss.

Postmodern theory further undermined normative views of culture, suggesting that culture itself is a Western construct privileging external observers' knowledge creation (etic) over that of insiders (emic) [38]. From this perspective, anthropology—and the study of culture in general—serves only to perpetuate the various forms of intellectual colonialism Western powers used to establish and justify institutions of control over Indigenes in the first place. Thus, for postmodernists, it is impossible to speak of culture in singular, normative, or monolithic terms. Instead, cultures consist of the various social performative arenas in which a diversity of irreconcilable meanings are generated, communicated, and interpreted-lacking anything resembling the coherency the concept represented for prior intellectual traditions [13]. Although there remains considerable difference of opinion within the social sciences and humanities regarding these radical definitional distinctions, the impacts of postmodern philosophy on contemporary conceptions of culture cannot be overstated.

With such divergent philosophical differences besetting the discipline most closely associated with the concept of culture, it is not surprising that those outside anthropology would employ definitions with which they are more comfortable or that seem more concrete. Unfortunately, these perspectives all too commonly reflect long-rejected notions of culture as brittle, normative, environmentally determined, and place-bound. Statements affirming the "inextricable link" between cultural and biological diversity, only reinforce such views, without adequately differentiating between the mechanisms of cultural reproduction and those of biological systems [45]. Perhaps demonstrating the pervasive influence of Julian Steward's work, many scholars continue to espouse views equating Indigenes with their natural environments, depicting these cultures as if they were merely another form of apex predator, or perhaps more commonly, locally evolved guardians of the diversity of their natural environments. This is why many scholars immediately see threats to biodiversity as simultaneous threats to cultural diversity. Once again, Indigenes are rendered as timeless, place-bound children of nature, while Westerners are allowed to operate within a very different epistemological space, free to roam the globe, measure the passage of time with atomic precision, and actively alter both their cultures and environments.

Frustratingly, just as outdated ecological models once suggested the existence of 'normal' baselines for ecosystems rather than recognizing that all natural systems are subject to developmental cycles and change, many continue to see Indigenous cultures through a similar static lens. Archaeologist and cultural ecologist Clark Erickson suggests, "the 'New Ecology' provides a more sophisticated perspective for understanding the dynamics of cultural landscapes than the traditional equilibrium and homeostatic model... environments are dynamic and historically contingent" ([46], p. 635). As Fekri Hassan eloquently states, "culture is a product not of coping with the environment, but of coping with the human mind in the presence of others" ([27], p. 219). I suggest, following Erickson [46-48], Balée [49-51], and others [52], that those concerned with Indigenous cultural sustainability must adopt similar perspectives when considering cultural baselines and normalcy among the groups they study.

The conflation of Indigenous cultures with natural environments has led to depictions of Indigenous people as primitive ecologists, living in perfect harmony with each other and the natural world [53-56]. An example of this thinking is found in depictions of cultural and evolutionary stability 
among the Bushmen of the Kalahari, with some suggesting that these were the living descendants of more foraging groups that originated more than 40,000 years ago [57]. Thus, the implication was that they were a stone-age people whose subsistence adaptations demonstrated the long-term stability of "primitive" cultures in balance with their environment. However, as more recent anthropological research by Robert Gordon [58] demonstrates, this illusion of cultural immutability owes more to the collective imagination and representational categories of European colonists rather than anything approaching anthropological or archaeological truth. There are most certainly very real threats to the cultural survival of West African foragers, but bathing their history in the Western trope of the vanishing "savage" does nothing to stem the tide of these cultural encroachments [58].

But why would some prefer misleading reconstructions of cultures and environments to their actualities? As Jacob Gruber suggests, "The savage was the vulnerable party; it was he who was so constantly the focus of salvage ethnography. The loss of the savage, so real to the anthropologist, pointed up his value. Salvage provided the opportunity for human contact and human contrast. Here savagery met civilization, the presumed past met the present, stability met change" ([10], p. 8). Hinton goes further, suggesting that modernity itself demanded the creation of Indigenous peoples who were the very opposites of civilized Europeans [59]. As Shepard Krech's [60] recent analysis of the pervasiveness and durability of these myths (despite ample evidence to their contrary) demonstrates, there appears to be a deep-seated ontological need among many in the West for Indigenes to be, and have been, ecological innocents. Thus, buttressed by the notion that some groups were capable of living in harmony with nature, stark contrasts could be drawn with the well-documented environmentally destructive tendencies of Western capitalism.

A parallel case is found in reconstructions of Lowland Maya civilization from the 1940s to the 1960s. During this period, archaeologists and popular media portrayed ancient Maya city-states as ecologically minded societies, ruled by star gazing priests who ruled over peaceful kingdoms $[61,62]$. These views became accepted dogma concerning the Classic Period Maya, despite a wide variety of portrait art, elaborately painted ceramics, large polychrome murals, and other evidence that wide spread warfare, violent conquest, and ritual human sacrifice were integral components of Maya statecraft [63]. Additionally, sites like Copán, Honduras presented clear evidence of the role of anthropogenic environmental degradation in the eventual decline of these polities [64]. But why would archaeologists and others actively avoid engaging these sources of evidence in their reconstructions of ancient Maya civilization? One explanation is that given the near continual warfare waged by Western powers during the first half of the 20th century, the idea that complex city-states could have flourished in relative peace and harmony presented a seductive counter-image to that of the carnage perpetrated by Western nations [65]. After all, if the Maya could live in harmony, why not us? Thus, once again Indigenous culture was appropriated to meet a Western existential/ontological crisis.

Although there are most certainly a range of very real threats posed to the survivability of global Indigenous cultures, much of the epistemology underlying present claims of cultural and ecological sustainability must be revised in light of contemporary anthropological perspectives on culture. What are needed are intellectual projects that do not demand a priori Indigenous environmental blamelessness [60]. In addition, these studies must recognize the autonomy and sovereignty of Indigenes in shaping their own environmental development and conservation priorities [36]. Of course, it would be exceptionally naïve to propose that Indigenous people are always treated as equal partners 
when Nation-states, multi-national corporations, or even philanthropically-minded NGOs propose development schemes involving Indigenous lands and resources. However, Western actors must explicitly acknowledge that Indigenes are fully modern people, not representatives of previous evolutionary epochs from the remote cultural past.

Additionally, some scholars fail to appreciate the level of apprehension many Indigenous people - and minorities in general — feel toward outside experts. Since scientists are commonly drawn from the ranks of the same Western societies responsible for many of the forces negatively impacting them, Indigenes often express skepticism regarding the motivations of the scientific community. Even Amerind groups fully engaged with mainstream Western cultural institutions commonly demonstrate high levels of mistrust regarding Western knowledge claims. As recent ethnographic research by Brian Gilley [66] demonstrates, HIV/AIDS prevention efforts promoted by the Indian Health Service (HIS) and local boards of health are often met with cynicism within Amerind communities. In fact, many of these communities subscribe to specific forms of disease etiology bordering on conspiracy theories, with some suggesting that HIV/AIDS was developed by the United States government to complete the genocide began five centuries ago with the initial introduction of European diseases previously unknown among Amerinds (e.g., smallpox, influenza). Thus, condom use and other government-supported programs designed to prevent the spread of HIV/AIDS frequently are seen as probable vehicles for the creation of additional cases of infection among Amerinds.

Given the controversy surrounding claims made by Patrick Tierney [67] in the book, Darkness in El Dorado: How Scientists and Journalists Devastated the Amazon, where he accuses geneticist James Neal and anthropologist Napoleon Chagnon of precipitating a deadly outbreak of measles among the Yanomami in the late 1960s, it is understandable that Indigenous peoples would remain slow to fully embrace all external offers of help. Although Tierney's most salacious claims were largely contradicted by an American Anthropological Association inquiry, other cases in which anthropology has been misused have left the discipline open to criticism and suspicion. Perhaps most damaging was the involvement of several prominent American social scientists-including anthropologists-in a clandestine 1960s Central Intelligence Agency (CIA) operation, codenamed Project Camelot, designed to provide information useful for predicting and controlling potential political unrest in Chile [68]. Additional revelations concerning secret nuclear radiation studies conducted on the citizens of Oak Ridge, Tennessee, the Tuskegee syphilis experiment, the forced sterilization of many Indigenes during the eugenics movement, and other clandestine United States government research on its citizens (some real and others imagined) have resulted in even the non-Indigenous expressing concern about the benevolent intentions of both the scientific community and government. Former U.S. President Ronald Reagan tapped into pervasive fears and mistrust of government when he stated, "The nine most terrifying words in the English language are: I'm from the government, and I'm here to help" [69].

With apprehension among Indigenes and considerable epistemological baggage among the scientific community, how then can Western forces best serve the cultural sustainability needs of Indigenous communities? As previously suggested, collaboration is possible, but it requires a willingness on the part of Western scholars to recognize the cultural expertise of the Indigenous. Rather than directing cultural conservation efforts, sustainability efforts must prioritize local knowledge over Western science and our forms of knowledge creation. Finally, rather than seeing 
change as anathema to cultural continuity and survival, it must be seen as a natural part of cultural evolution when mediated by internal cultural forces. Otherwise, we run the risk of continuing to crush Indigenous cultures under the weight of Western scientific expertise, projecting colonialist ontologies and existential priorities onto them, and making Indigenes something other than full members of the modern human community [21,22].

\section{Cultural Hybridity and Reindigenization}

Given its long history of engagement with non-Western societies, anthropology has produced a litany of studies related to efforts at cultural preservation, often under the harshest conditions of globalism [70-77]. However, unlike theories of dependency or World Systems developed in other social sciences in which the peripheries of history, culture, and economic development are populated by powerless, faceless Indigenes, most contemporary anthropologists ground their studies in analyses of Indigenous agency and resistance. This subtle, yet meaningful shift in perspective allows us to avoid seeing Indigenous culture change as an either/or dichotomy where they either become extinct when confronted with expanding Western cultural hegemony or must be rendered timeless and unchanging, like a well-worn photographic image. Anthropologists see ample room for cultural hybridity, where Indigenous cultures accommodate new social dimensions - a space where Diana Loren [70] suggests, “familiar meets unfamiliar"-but within Indigenous frames of reference [77]. Thus, cultural hybridity theory suggests that new cultures form within these engagements, representing not necessarily the end of a culture, but a new beginning. Viewed from this perspective, culture change doesn't mean the inevitable loss of culture, but a creative space where new forms of cultural understanding (and practice) are developed in the dynamism that exists in cross-cultural engagement [70]. Although developing these ideas more completely is beyond the immediate scope of this paper, views of hybridity have come to radically alter not only our understanding of culture change but language development and preservation as well.

Additionally, archaeologists see Indigenous interactions with the environment in vastly different ways than other scholars interested in these relationships. Instead of seeing an "inextricable link" between human cultures and their physical environments due to connections with subsistence resources, where threats to landholdings automatically equate threats to cultural continuity, archaeologists see these links in largely psychosocial terms. Landscapes are important to cultures not only because of their resource potential, but also because of their deep-seated symbolic meanings. As historical ecologists have repeatedly demonstrated [78-80], cultural landscapes are far more than the sum total of their physical properties. Carl Sauer [81] suggests that these "cultural landscapes" are "fashioned from the natural landscape by a culture group. Culture is the agent, the natural area is the medium, the cultural landscape the result." Similar ideas are expressed by William Balée [79], Roy Rappaport [80], and various other scholars who propose that historical ecology permits a deeper-culturally and historically nuanced-understanding of the complex relationships between people and their environments. Thus, particular locations are also important to individual groups because their cultural mythologies are commonly tied to landscape features. Additionally, most cultures have deep connections to place through ties to the physical remains of their deceased ancestors and ancient occupational sites as well. Thus, alienation from traditional territories represents a very 
different form of cultural threat than is appreciated by many scholars. As is demonstrated in each of the examples I discuss below, particular physical locations are vital to the health and continuity of Indigenous cultures and must be appreciated in the social terms as well.

In addition to the formation of new cultures, anthropologists have also witnessed-with growing regularity - explicit efforts to reinvigorate earlier cultural practices. Jackson and Ramirez [82] have examined the mobilization of language, material objects, and newly formed "rhetorics of indigeneity" in expressions of cultural revitalization among the Yanacona peoples of Columbia. They identify this as a case of "reindigenization," an explicit attempt to reverse the effects of acculturation and recover their Indigenous culture and identity. Unfortunately for the Yanacona and other groups attempting to revive past practices in the present, governments, NGOs, and other institutional forces have established the official criteria for defining "authentic" Indigenes, a legal recognition process that demands forms of genetic, cultural, and historical documentation that are commonly beyond the means of local groups to demonstrate [82]. Even when officials acquiesce to local assertions of Indigeneity, these claims are often challenged by outsiders (including government officials) in derisive language and assertions that those considered 'newly minted' Indigenes are engaged in political or economic opportunism.

Claims of ethnic continuity frequently center on claims related to "blood and soil" [82-87], with those capable of demonstrating long-term connections to certain locales afforded greater degrees of Indigenousness. Lynn Meskell [85] refers to these arguments as assertions of "territorial ethnicity" in which claims of ancestral connections to lands are made the basis of claims of identity. Thus, those claiming a "inextricable link" between cultural degradation and the loss of cultural diversity may have valid points, but not in the form such language originally suggested. In addition to the priority of land claims in assertions of Indigeneity, claims of connections to the distant past are also effective means of asserting Indigenous identities - thus the importance of having access to major archaeological sites [13,85-87]. However, to dwell merely on connections to the past runs the risk of continuing the practice of seeing Indigenous peoples as a different category of person from other modern peoples. Ian Hodder ([13], p. 877) examines this notion, stating "when a notion of inherent rights is linked to the notion that persons derive their rights to heritage by descent, the result is a dangerous conception of cultural heritage as basic, fundamental, God-given, absolute. In fact, we know that cultural identities are endlessly mixed, fluid, contested, shared." In addition, as Arjun Appadurai [88] suggests, it is not enough to build Indigenous identity around connections to a distant past, what is required are expressions of future hopes and aspirations.

$\mathrm{Li}$ [83] argues that resurgent claims of Indigenous identities are intimately tied to efforts countering dispossessions of tradition, history, culture, and land brought about by global capitalism. At the same time, the power of these claims has been recognized by forces opposed to development: "From the array of mechanisms through which capitalism is linked to indigeneity and dispossession, the one that stands out in the contemporary period is ... indigenous people up against wholesale displacement by dams, plantations, and other megaprojects. People resisting these projects who can argue that it is not just livelihoods but culturally distinct and ecologically sound ways of life that are being destroyed have captured public attention" ([83], p. 395). Unfortunately, such efforts usually seek to build a protective wall around Indigenes rather than equipping them with the cross-cultural knowledge necessary to counteract dispossessive forced in the long-term [83]. Hodder ([13], p. 870) views these "exclusionary" physical, historical, and cultural spaces as inherently flawed, stating, "Claims to the past based on 
fixed boundaries and close associations between people and cultures are contradicted by the evidence that culture is passed down through complex and fluid channels, heritage is continually being reproduced and reinterpreted, human groups and cultures are in the long term open and in flux."

\section{Cultural Collaboration}

I now turn to several examples of the contributions anthropological archaeology is making to contemporary cultural and environmental preservation efforts. I have chosen cases where the solutions to cultural sustainability might be considered less than ideal from the perspective of Western observers. Although the examples I present are based in archaeology, each involves scholars working closely with Indigenous communities as landscapes, ancient archaeological sites, environmental resources, and notions of culture heritage are all used as principal elements of cultural sustainability programs. Although archaeology is commonly thought of as dealing with ancient cultures, even this discipline can be of use to contemporary Indigenous peoples as they marshal aspects of the past to craft unique cultural identities in the present and look toward the future. What unites these cases is a particular form of collaborative engagement between anthropologists and Indigenous peoples that prioritizes the desires of local communities, rather than those of Western scholars.

\subsection{Returning Raised Field Agriculture to the Lake Titicaca Basin}

In the 1980s and 1990s, archaeologist Clark Erickson of the University of Pennsylvania undertook a series of archaeological investigations in the Lake Titicaca basin of Bolivia and Peru. The accepted wisdom of the time, based on prior archaeological and historical environmental studies, was that the Titicaca basin and most of the South Central Andes experienced a centuries-long drought that led to general cultural collapse around A.D. 1150 [89]. Based in 'New Ecology' rather than traditional environmental determinist perspectives, Erickson's research has provided ample evidence of cultural continuity during this period and led him to question the extent of this purported collapse. Erickson ([46], p. 641) documented a range of long-standing cultural responses to drought mitigation representing a "complex indigenous knowledge system that includes a sophisticated agricultural technology and elaborate social strategies to mitigate both short- and long-term climatic fluctuations. This knowledge has been worked out and fine-tuned by hundreds of generations of farmers. It has been passed down through daily practices and oral history from generation to generation."

One of the principal forms this knowledge takes is the construction of raised agricultural fields both within Lake Titicaca itself and along lake margins. These are relatively modest constructions, rising no more a half-meter, but surrounded by artificial canals approximately $1.0-1.5 \mathrm{~m}$ in depth [46-48]. Erickson collaborated with local Quechua, Aymara, and Uru peoples, moving from a primarily historical interest in the nature of Andean agricultural productivity to a series of experiments in the productive capacities of these agricultural systems. Results of these experiments revealed that subsistence crop production could be more than doubled using these systems, even when compared to more "modern" agricultural practices utilizing artificial fertilizers [47]. Furthermore, these systems are capable of sustaining such yields for several years due to the natural production of nitrogen fixing algae in their surrounding canals. Canals also serve to conserve rainfall, control lake levels, mitigate seasonal droughts, and promote the development of useful aquatic plants and fish [46-48]. 
Despite the promising results of Erickson's raised field agricultural experiments, local farmers have been slow to adopt these practices. Erickson suggests that some of this reluctance is based in the cultural conservatism that often greets the introduction of novel subsistence practices. Although raised fields were the dominant form of local agriculture in the pre-Hispanic past, until Erickson's work, local farmers had abandoned those traditions and accepted Western-introduced farming practices. In addition, raised field agricultural practices have been promoted by many political Leftists as representing a return to the communal traditions of the Andean past [47]. Thus, close association with a set of political and social ideologies that have led to bloodshed and revolutionary insurgencies in the region have also reduced the potential impact of these reintroduced practices. A final obstacle seems to be present land-holding practices in the Titicaca region that thwart opportunities to build the contiguous networks necessary for these raised field systems to reach their maximum levels of productivity [47].

Despite these impediments, Erickson's work-limited in scale though it is - has produced far more positive impacts on local agricultural practices than other agro-development projects imported into the Andes from external agricultural experts. The reintroduction of raised field agriculture also promises a level of environmental and cultural sustainability not offered by these other schemes. As Erickson and Candler ([48], p. 245) suggest, competing land development efforts in the region "are ecologically unsound, relying on introduced crops and farming practices developed for completely different environmental zones. More importantly, these systems are socially and economically inappropriate, relying on heavy capital inputs such as mechanization, petro-chemicals, and imported seed."

\subsection{Restoring Indigenous Connections to Copán}

One of the unfortunate truths of archaeological research is that many of the sites critical to our research are endangered by modern development. Like any endangered resource, there are only so many 1,000 or 100,000 year old archaeological sites that can provide useful information on the human past. The destruction of any archaeological site thus represents a permanent negative impact to our ability to recover specific knowledge about the past. To combat this destruction, many nations have passed preservation laws designed to protect these vital historical and cultural resources. In the case of major archaeological sites, like those designated World Heritage Sites, government protection has been offered to ensure that these critical resources will be protected from development [13,82-87]. Although these efforts afford greater levels of protection for these sites, a common, unintended side effect has been the distancing of modern Indigenes from places vital to their cultural patrimony. Thus, not only have many sites been placed off limits to potential developers, they have also been placed off limit to groups descended from those who build and occupied these important places.

An unfortunate example of this heritage distancing is found at the archaeological site of Copán, Honduras. Defined as the "alienation of contemporary inhabitants of a landscape from the tangible remains or intangible practices of the past", distancing groups from aspects of their cultural patrimony also "denies the heritage rights of indigenous peoples" and "endangers the conservation of ancestral landscapes" ([87], p. 80). At Copán, the local Ch'orti' Maya have been alienated from the site, left out of important discussions about conservation and excavation, and remain invisible in the dissemination of site information to tourists [87]. Thus, visitors to Copán are not encouraged to see cultural links between contemporary Indigenes living in the site's vicinity, but are instead left to 
contemplate the enigmatic collapse and disappearance of the once powerful Maya. As Long and Smith suggest, “... nation states use the World Heritage system to further their own development and political agenda ... [in ways that have] little to do with preservation of heritage for its 'intrinsic value" ([90], p. 174). Furthermore, Ian Hodder [13] and Lynn Meskell [85] question such actions on behalf of the heritage preservation community on the bases of both human rights and social justice.

Over the past decade, the exclusion of local groups from Copán and other major archaeological sites in Mexico, Belize, and Guatemala, has led to political activism on the part of Amerind groups and increased assertions of Indigenous ethnic identity [87]. Ch'orti' suggest that their lack of access to Copán and other major sites represents nothing less than the colonization and commodification of their past $[84,86,87]$. Additionally, with knowledge of the profit to be made through participation in the elicit international antiquities trade, some contemporary Maya are now considered threats to site conservation at both well-known sites like Copán and those that lack official government protection. Since the massive profit generated by tourist activities at their ancestral sites largely bypass Amerind hands, can it be at all surprising that some would turn to the antiquities trade as their only viable way of profiting from their own cultural heritage? McAnany, Parks, and Murata [86,87] view this trade in looted antiquities (a violation of both national and international laws in almost all cases) as one of the hidden forces of globalization acting to further distance modern Ch'orti' from their own cultural past.

Parks, McAnany, Murata and others are working with local Maya groups in a collaborative effort to mitigate the "disenfranchisement of local communities from a distant past and [rectify] the absence of dialogue about the significance and value of pre-Columbian heritage beyond that of commodification for tourism ..." ([87], p. 85). These efforts at Copán, and similar programs at other major culture heritage centers and archaeological sites globally, are now seen as part of an overarching framework of International human rights, reserving a preferential place at the table for those with the closest cultural connections to major archaeological sites [13,85-87]. At Copán, these actions include both education outreach concerning the importance of archaeological conservation, the damages inflicted on culture heritage by looting and the antiquities market, as well as the development of new economic opportunities within the culture heritage sector for Ch'orti' and other Maya. It should be noted that these efforts are not directed by archaeologists, but are part of an explicit recognition that knowledge production in archaeology is a Western scientific construct $[86,87]$. Thus, these programs are designed to "complement and enrich oral histories and indigenous ways of knowing the past", not replace them ([86], p. 431).

However, the suggestion that indigenes can meet their needs by simply seeking employment within the existing culture heritage arena or the tourist industry is not without considerable pitfalls. As a recent auto-ethnographic account by Bunten [91] demonstrates, Indigenes involved in these industries must face the dual reality of being considered a sell-out by other members of their culture while simultaneously becoming a commodity themselves. Bunten calls this process self-commodification, defined as "a set of beliefs and practices in which an individual chooses to construct a marketable identity product while striving to avoid alienating him-or herself ... Self-commodification, thus, involves any type of product performance that requires the individual to adjust his or her values, emotions, or both, to achieve an economic goal ..." ([91], p. 381). Additionally, tourists' preconceptions about what they will experience and what indigenes should ideally be like, create inauthentic cultural experiences directed by tourists, and for tourists, not indigenes [91,92]. Thus, as 
Bunten argues, "[cultural] heterogeneity is erased in favor of a standardized tour script" ([91], p. 386). This standardization leads to Indigenous culture being prepackaged, marketed, and sold in an effort to meet the "expectations, fantasies, and mythologies" of the tourist/consumer ([93], p. 386).

\subsection{Redefining Amazonia}

The Amazon River basin holds a special place in the hearts and minds of ethnologists, archaeologists, ecologists, and the general public. Given its immense size, ecological diversity, relative impenetrability, and a common view that Amazonia represents a pristine natural environment that has been impacted only minimally by humans prior to the modern era, the Amazon basin is frequently invoked as a natural paradise that must be preserved from development at all costs. Such views were formed at a time when our knowledge of Amazonian Indigenous cultures consisted of studies of relatively small groups (in demographic terms) scattered throughout the dense forest canopy, practicing a mixed form of subsistence economy based on foraging, fishing, and horticulture. Given the small sizes and general isolation of these Indigenous groups, it was proposed that they represented long-term cultural adaptations to local natural environments that had been relatively stable over millennia. Furthermore, given the poor abilities of Amazonia soils to support intensive agriculture, it was assumed that the carrying capacity of the natural environment had also acted to limit the growth, and impact, of humans in Amazonia [94-96]. Thus, conventional wisdom was that the Amazon had always been a wild "counterfeit paradise," offering few environmental opportunities capable of supporting anything more than small-scale, widespread, sporadic human occupations [97].

The only problem with these views is that recent archaeological research demonstrates that many areas of the Amazon basin are almost completely anthropogenically-produced "artificial" environments. Investigations by Michael Heckenberger and his colleagues in the Upper Xingu Valley, and a team led by Clark Erickson in the Santa Ana de Yacuma region of Bolivia on the western edge of the Amazon, have demonstrated that Amazonia was once home to much larger Amerind populations than presently reside in the region. This research has also demonstrated that areas boasting some of the highest levels of ecological diversity in Amazonia are the result of human-generated Amazonian Dark Earth (ADE) (terra preta) soils produced by the introduction of organically enriched soils to augment soil productivity and plant growth $[96,98,99]$. Erickson's work also has shown that the western edges of Amazonia supported large pre-Hispanic populations that utilized raised field agriculture similar to that he identified in his earlier research in the Lake Titicaca basin, built complex earthworks, and linked their communities with a complex series of artificial canals. The introduction of European diseases early in the sixteenth century appears largely to have been responsible for dramatically reducing Amazonia populations to their modern levels and the general abandonment of these subsistence practices.

Thus, prior claims that Amazonian cultures had developed harmonious, non-intensive exploitation strategies that left only minimal impacts on local environments have been refuted [54,55]. However, as this new research demonstrates, these environmental exploitation strategies did not lead to deforestation and threaten local ecological communities, but served to enhance them. Erickson's experimentation with restoration of these systems demonstrates not only the sustainability of these practices, but their ability to produce greater levels of bio-diversity per square meter than are presently 
found in Amazonia [46-48]. Additionally, presumptions of the relative political sophistication and sociopolitical scales of Amazonian cultures also must be reassessed [52,95]. As would be expected, scholars in other disciplines have expressed skepticism of these findings given the challenge they present to accepted dogma concerning both Amazonian ecosystems and the human impacts on these environments. Rather than a negative, however, it is hoped that these findings will encourage other scholars to engage in examinations of Indigenous environmental management systems as "keys to future approaches to land use and land rights", not only in the Amazon, but in other areas as well.

I would like to be explicit in stating that these recent findings do not suggest that protecting Amazon basin environments and their human inhabitants are not critical priorities for Western scientists. As Heckenberger ([95], p. 206) makes clear, "agro-pastoral expansion and other development practices" present immediate threats for the "rapid degradation" of local Amazonian environments. Heckenberger, Erickson, and others have used their emerging insights concerning the enhancement of local biodiversity within the Amazon basin by anthropogenic means to contrast these ancient practices with the destructive tendencies of modern development schemes in the region. Such efforts highlight ways of intensifying land use to meet growing demands without necessarily doing so extensively [100]. Initial results from the reintroduction of these practices suggest they are capable of producing increased environmental diversity and restoring local forest cover, while also generating greater profits - and requiring less capital-intensive investment - for Indigenous peoples [46-48]. Although these new insights have forced us to change many long-accepted notions about Amazonian environments and Indigenous cultures, they hold the promise of restoring both sustainable environmental and cultural practices to the region.

\subsection{Casino Development at Hickory Ground (Ocheopofau)}

Although it would be wonderful if all archaeological engagements with Indigenous communities resulted in the preservation of both environmental (and archaeological) resources and cultural traditions, the expansion of global capitalism has convinced many groups that they can only successfully preserve their cultural traditions by developing local environmental resources. In such situations archaeologists commonly strive to serve extant community development needs while also suggesting ways to preserve archaeological and other resources. An example from my own archaeological research in Alabama with the Poarch Band of Creek Indians at the site of Hickory Ground (Ocheopofau) (site number 1Ee199) demonstrates the inherent tensions that frequently accompany such collaborations.

Hickory Ground served as the last capital of the Creek Nation in Alabama [101]. It also was home to the last Creek council fire before the forced removal of most Creeks from their Southeastern homelands to Indian Territory (Oklahoma) on the Trail of Tears in the 1830s-giving the site heightened importance in the cultural memory and sacred geography of Creek peoples. When the site was threated by private development in the early 1990s, the State of Alabama purchased the property and transferred title to the Poarch Band of Creek Indians, the only Federally recognized Creek group in the state. Although it was anticipated that the Poarch Band would preserve the site from development given its importance in Creek history, when a twenty-year protective covenant expired in 2002, the Poarch Band announced plans to build a casino and gaming complex on the site. Despite a firestorm of 
controversy surrounding the proposed casino from the Muscogee (Creek) Nation of Oklahoma, the largest Federally recognized Creek group, and a coalition of non-Native American groups opposed to the casino, the project continued [102,103].

Although I was not the principal investigator on this project, I assisted the project director, Dr. John W. Cottier of Auburn University, by teaching four University of Illinois at Chicago summer field schools at Hickory Ground. This archaeological research was undertaken under an Archaeological Resources Protection Act of 1979 (ARPA) permit and a programmatic agreement with the Poarch Band that sought to focus our excavations within the planned footprint of the casino and its supporting infrastructure. Unlike the vast majority of American archaeological research projects, all field excavation and laboratory analysis methods received prior approval from the Tribal Historic Preservation Office, with no human remains, burial goods, or other items deemed critical elements of cultural patrimony by the Poarch Band, removed from tribal property. Thus, the Tribe was given complete control over all aspects of the archaeological research and exerted this authority in a variety of ways. The Poarch Band undertook reburial of all human remains and funerary objects on site, retained control over all other cultural materials, project notes, maps, and other research records, and maintains editorial supervision over the publication of detailed information regarding archaeological investigations at the site.

Despite Tribal control over our archaeological investigations and the casino development at Hickory Ground, there remains considerable disagreement among both Native American groups and the professional archaeological community over development of the Hickory Ground site. This situation has led to a series of grassroots efforts to halt additional development of the site, including the formation of a "Save Hickory Ground" Facebook site [104], formal legal action by the Muscogee (Creek) Nation of Oklahoma [105,106], and editorials in Native American media disparaging the authenticity of any Native American group that would sacrifice their ancestral heritage for the "White Man's money" [103,107].

These disputes arose despite plans for the Hickory Ground casino complex that include an interpretive center and site museum designed to tell the story of Hickory Ground and other aspects of Creek history from a decidedly Creek perspective. Additionally, profits from the casino have permitted the Poarch Band to address a series of chronically persistent social, political, and economic issues, including: (1) the creation of several ancillary Tribal business enterprises that have effectively eliminated unemployment among Tribal members; (2) the establishment of a college scholarship fund that permits all members to attend college; (3) the purchase of other significant Creek archaeological sites in Alabama to ensure their future conservation; (4) the creation of several cultural and language preservation efforts to ensure the perpetuation of Tribal traditions; and (5) the distribution of economic benefits among Tribal members to eliminate what has historically been one of the most povertystricken and politically marginalized minority groups in Alabama.

Although we had (and have) a range of concerns about the nature of these developments at Hickory Ground, the overriding anthropological principles of autonomy, sovereignty, and respect for Indigenous decision-making means that those involved in the project have tried to use their professional skills to consult and advise the Tribe, without seeking to control their actions. Certainly the development of an historically important archaeological site-itself a non-renewable resource-represents a form of cultural loss for Creek peoples, but in the calculus of the Poarch Band, 
what development of this Hickory Ground means to current and future Tribal sustainability efforts supersedes these concerns.

\section{Conclusions}

As I hope is clear from the previous discussion, cultures are dynamic, variable, lack well-defined physical and historical boundaries, and always changing. There can be little doubt that the rapid pace of change brought about by the present era of instant global communication, commodification, and development represent a series of unique threats to Indigenous cultures. What is much less clear is what we in the Western scientific community can do to counter these forces. As I assert throughout, however, any effort we undertake must be made in collaboration with Indigenous groups rather than on their behalf [108-111]. As Maffi ([112], p. 612) suggests, "Ultimately, the most fundamental impetus for the protection and maintenance of biocultural diversity can come, not from top-down efforts, but only from the ground-up action of Indigenous and other societies worldwide whose languages, cultural identities, and lands are being threatened by global forces."

Many scholars - archaeologists and museologists in particular-have frequently marginalized contemporary Indigenous voices regarding our recovery, interpretation, publication, display, and curation or material elements far more closely related to their cultural ancestory than our own. These situations are particularly acute in situations like that of Machu Picchu, where Western institutions, Yale University in this case, have refused to return items of cultural patrimony out of a sense that their commitment to the preservation of the object is greater than any of its responsibilities to Indigenous descendant communities. Additionally, as the case of Machu Picchu further demonstrates, the feeling that some things are so precious they can't be entrusted to Indigenous hands epitomizes the intellectual hubris of many Western actors and institutions [113-117].

As the archaeological case studies I summarize demonstrate (particularly my own at Hickory Ground), results of collaborations with Indigenous peoples may not produce results that resemble what we originally imagined. The past isn't a foreign country after all, but serves as a potent resource for crafting identities in the present. Western scholars engaged in cultural sustainability efforts must be cognizant that they are dealing with fully modern peoples who freely mine their ancestral cultures in myriad novel ways that variously assert, claim, and create modern identities. Our goals should not be cultural stasis and isolation, but rather dynamic cultural revivals that benefit from the past - and its unique historical cultural precedents-in creative assertions of identities in the present.

\section{Acknowledgments}

I would first like to acknowledge the impact that more than 20 years of on-going collaboration with the Poarch Band of Creek Indians and the Muscogee (Creek) Nation of Oklahoma have had on my thoughts regarding cultural sustainability and survival. Although these groups have adopted different (and sometimes discordant) views regarding the practice of their cultures, this diversity in approaches has helped me to understand culture as plural, conflictual, hybrid, and dynamic. I also wish to thank Andrew Beaupré for sharing his insights on an earlier draft of this paper. Additionally, I am profusely thankful to three anonymous reviewers who provided a range of excellent criticisms that have allowed 
me to strengthen my arguments in many ways. Finally, I would like to thank the editor of this special issue, Anders Breidlid, Antonio Vieira, Andres Gartmann, and the entire staff at Sustainability for encouraging me to contribute what I'm sure is a dissident voice in this collection of papers.

\section{Conflict of Interest}

The author declares no conflict of interest.

\section{References and Notes}

1. Darnell, R. And Along Came Boas; John Benjamins publisher: Philadelphia, PA, USA, 1998.

2. Darnell, R. North American Traditions in Anthropology. In A New History of Anthropology; Kuklick, H., Ed.; Blackwell: Malden, MA, USA, 2008; pp. 35-51.

3. Gonzalez, S. Intermarriage and assimilation: The beginning or the end? Wicazo Sa Review 1992, 8, 48-52.

4. Gruber, J.W. Ethnographic salvage and the shaping of anthropology. Am. Anthropol. 1968, 61, 379-389.

5. Boas, F. The history of anthropology. Science 1904, 20, 513-524.

6. Boas, F. Anthropology and Modern Life; W.W. Norton and Company Inc.: New York, NY, USA, 1928.

7. Throsby, D. Linking cultural and ecological sustainability. Int. J. Divers. Organ Communities Nations 2008, 8, 15-20.

8. Beck, U. World Risk Society; Polity Press: Cambridge, UK, 1999.

9. Barthel-Bouchier, D. Cultural Heritage and the Challenge of Sustainability; Left Coast Press: Walnut Creek, CA, USA, 2012.

10. Lewellen, T.C. The Anthropology of Globalization; Greenwood: Westport, CT, USA, 2002.

11. Bekerman, Z.; Kopelowitz, E. Introduction. In Cultural Education-Cultural Sustainability; Bekerman, Z., Kopelowitz, E., Eds.; Routledge: New York, NY, USA, 2008; pp. 1-6.

12. Martínex-Ballesté, A.; Martorell, C.; Caballero, J. Cultural or ecological sustainability? The effect of cultural change on sabal palm management among the lowland Maya of Mexico. Ecol. Soc. 2006, 11, 27.

13. Hodder, I. Cultural heritage rights: From ownership and descent to justice and well-being. Anthropol. Q. 2010, 83, 861-882.

14. Dobyns, H.F. Their Number Became Thinned: Native American Population Dynamics in Eastern North America; University of Tennessee Press: Knoxville, TN, USA, 1983.

15. Rousseau, J. Discourse on the Origin of Inequality; Hackett: Indianapolis, IN, USA, 1992.

16. Maaka, R.; Fleras, A. The Politics of Indigeneity; Otago University Press: Dunedin, New Zealand, 2005.

17. Reyes, A.; Kaufman, M. Sovereignty, Indigeneity, Territory. S. Atl. Q. 2011, 110, 505-525.

18. Tsosie, R. The new challenge to native identity. Wash. Univ. J. Law Pol. 2005, 18, 55-98.

19. Forte, M.C. Introduction: Indigeneities and Cosmopolitanisms. In Indigenous Cosmopolitans; Forte, M.C., Ed.; Peter Lang: New York, NY, USA, 2010. 
20. Solomon, R.C. The Bully Culture: Enlightenment Romanticism, and the Transcendental Pretense, 1750-1850; Littlefield Adams: Totowa, NJ, USA, 1992.

21. Holtorf, C. Beyond crusades. World Archaeol. 2005, 37, 544-551.

22. Holtorf, C. Archaeology is a Brand! Left Coast Press: Walnut Creek, CA, USA, 2007.

23. Deloria, V., Jr. Custer Died for your Sins; Macmillan: New York, NY, USA, 1969.

24. Deloria, V., Jr. God is Red; Putnam: New York, NY, USA, 1973.

25. Deloria, V., Jr. Behind the Trail of Broken Treaties; University of Texas Press: Austin, TX, USA, 1985.

26. Echo-Hawk, W.R. In the Courts of the Conqueror; Fulcrum: Golden, CO, USA, 2010.

27. Hassan, F.A. Objects of the Past: Refocusing Archaeology. In A Future for Archaeology; Layton, R., Shennan, S., Stone, P., Eds.; University College London Press: London, UK, 2006; pp. 217-227.

28. O'Neill, C. Rethinking Modernity and the Discourse of Development in American Indian History, an Introduction. In Native Pathways: American Indian Culture and Economic Development in the Twentieth Century; Hosmer, B., O'Neill, C. Eds.; University Press of Colorado: Boulder, Colorado, USA, 2004.

29. Blakey, M.L. Intrinsic social and political bias in the history of American physical anthropology with special reference to the work of Ales Hrdlicka. Critiq. Anthropol. 1987, 7, 7-35.

30. Morton, S.G. Crania Americana; J. Dobson: Philadelphia, PA, USA, 1839.

31. Silverberg, R. Mound Builders of Ancient America; Ohio University Press: Athens, OH, USA, 1970.

32. Williams, S. Fantastic Archaeology; University of Pennsylvania Press: Philadelphia, PA, USA, 1991.

33. Willey, G.R.; Sabloff, J.A. A History of American Archaeology, 3rd ed.; W.H. Freeman: New York, NY, USA, 1993.

34. Feder, K. Frauds, Myths and Mysteries, 7th ed.; McGraw Hill: New York, NY, USA, 2010.

35. Kipling, R. The White Man's Burden. New York Tribune, 5 February 1899.

36. Easterly, W.R. The White Man's Burden: Why the West's Efforts to Aid the Rest Have Done So Much Ill and So Little Good; Penguin Press: New York, NY, USA, 2006.

37. Herskovits, M.E. Introduction. In Acculturation in the Americas; Tax, S., Ed.; University of Chicago Press: Chicago, IL, USA, 1952; pp. 48-63.

38. Said, E. Orientalism; Vintage Books: New York, NY, USA, 1979.

39. Wissler, C. Ethnic types and isolation. Science 1906, 23, 147-149.

40. Wissler, C. The Relation of Culture to Environment from the Standpoint of Invention. Popular Science Monthly, August 1913, pp. 164-168.

41. Wissler, C. The Relation of Nature to Man in Aboriginal America; Oxford University Press: New York, NY, USA, 1926.

42. White, L. Energy and the evolution of culture. Am. Anthropol. 1943, 45, 335-356.

43. Steward, J.H. Theory of Culture Change; University of Illinois: Urbana, IL, USA, 1955.

44. Geertz, C. The Interpretation of Cultures; Basic Books: New York, NY, USA, 1973.

45. Posey, D.A.; Dutfield, G. International Society of Ethnobiology. Available online: http://ethnobiology.net/global-coalition/declaration-of-belem/ (accessed on 22 October 2012). 
46. Erickson, C.L. Neo-environmental determinism and agrarian "collapse" in Andean prehistory. Antiquity 1999, 73, 634-642.

47. Erickson, C.L. Raised field agriculture in the Lake Titicaca Basin: Putting ancient agriculture back to work. Expedition 1988, 30, 8-16.

48. Erickson, C.L.; Candler, K.L. Raised Fields and Sustainable Agriculture in the Lake Titicaca Basin of Peru. In Fragile Lands in Latin American: Strategies for Sustainable Development; Browder, J. O., Ed.; Westview Press: Boulder, CO, USA, 1989; pp. 230-248.

49. Balée, W.; Erickson, C.L. Time and Complexity in Historical Ecology; Columbia University Press: New York, NY, USA, 2006.

50. Balée, W. Indigenous adaptation to Amazonian palm forests. Principes 1988, 32, 47-54.

51. Balée, W. The culture of Amazonian forests. Adv. Econ. Bot. 1989, 7, 1-21.

52. Heckenberger, M.J. Russell, J.C.; Fausto, C.; Toney, J.R.; Schmidt, M.J.; Pereira, E.; Franchetto, B.; Kuikuro, A. Pre-Columbian urbanism, anthropogenic landscapes, and the future of the Amazon. Science 2008, 321, 1214-1217.

53. McGregor, D.P. Hawaiian Subsistence, Culture and Spirituality, and Natural Biodiversity. In Cultural and Spiritual Values of Biodiversity; Posey, D.A., Ed.; UNEP and Intermediate Technology Publications: London, UK, 1999; pp. 114-116.

54. Posey, D.A. Cultural and Spiritual Values of Biodiversity: A Complementary Contribution to the Global Biodiversity Assessment. In Cultural and Spiritual Values of Biodiversity; Posey, D.A., Ed.; UNEP and Intermediate Technology Publications: London, UK, 1999; pp. 1-19.

55. Berkes, F. Religious traditions and biodiversity. Encyclopedia of Biodiversity 2001, 5, 109-120.

56. Cunningham, A.B. Applied Ethnobotany: People, Wild Plant Uses and Conservation; Earthscan: London, UK, 2001.

57. Eldredge, E.A. The Bushman Myth: The Making of a Namibian Underclass. African Econ. History 1993, 21, 200-203.

58. Gordon, R.J. The Bushman Myth: The Making of a Namibian Underclass; Westview Press: Boulder, CO, USA, 1992.

59. Hinton, A.L. The Dark Side of Modernity: Towards an Anthropology of Genocide. In The Anthropology of Genocide; Hinton, A.L., Ed.; University of California Press: Berkeley, CA, USA, 2002; pp. 1-41.

60. Krech, S., III. The Ecological Indian: Myth and History; W.W. Norton: New York, NY, USA, 2000.

61. Schele, L.; Freidel, D. A Forest of Kings; William Morrow and Company Inc.: New York, NY, USA, 1990.

62. Schele, L.; Miller, M.E. The Blood of Kings: Dynasty and Ritual in Maya Art; Kimball Art Museum: Ft. Worth, TX, USA, 1986.

63. Fash, W.L. Changing Perspectives on Maya Civilization. Annu. Rev. Anthropol. 1994, 23, 181-208.

64. Folan, W.J.; Faust, B.; Lutz, W.; Gunn, J.D. Social and Environmental Factors in the Classic Maya Collapse. In Environment on the Yucatán Peninsula: From Ancient Maya to 2030; Lutz, W., Prieto, L., Sanderson, W., Eds.; International Institute for Applied Systems Analysis: Laxenburg, Austria, 2000; pp. 2-32. 
65. Keeley, L.H. War Before Civilization: The Myth of the Peaceful Savage; Oxford University Press: New York, NY, USA, 1997.

66. Gilley, B.J. "Snag Bags": Adapting Condoms to Community Values in Native American Communities. Cult. Health Sex. 2006, 8, 559-570.

67. Tierney, P. Darkness in El Dorado: How Scientists and Journalists Devastated the Amazon; W.W. Norton: New York, NY, USA, 2000.

68. Horowitz, I.L. The Rise and Fall of Project Camelot: Studies in the Relationship between Social Science and Practical Politics; MIT Press: Cambridge, MA, USA, 1967.

69. The Quotations Page. Available online: http:/www.quotationspage.com/quote/33742.html/ (accessed on 22 October 2012).

70. Loren, D.D. In Contact: Bodies and Spaces in the Sixteenth- and Seventeenth-Century Eastern Woodlands; AltaMira: Lanham, MD, USA, 2008.

71. Stoler, A.L. Along the Archival Grain: Epistemic Anxieties and Colonial Common Sense; Princeton University Press: Princeton, NJ, USA, 2009.

72. Cooper, F.; Stoler, A.L. Tensions of Empire: Colonial Cultures in a Bourgeois World; University of California Press: Berkeley, CA, USA, 1997.

73. Comaroff, J.; Comaroff, J.L. Modernity and its Malcontents: Ritual and Power in Postcolonial Africa; University of Chicago Press: Chicago, IL, USA, 1993.

74. Scott, J.C. The Moral Economy of the Peasant: Rebellion and Subsistence in Southeast Asia; Yale University Press: New Haven, CT, USA, 1976.

75. Scott, J.C. Weapons of the Weak: Everyday Forms of Peasant Resistance; Yale University Press: New Haven, CT, USA, 1985.

76. Scott, J.C. Domination and the Arts of Resistance: Hidden Transcripts; Yale University Press: New Haven, CT, USA, 1990.

77. Latour, B. We Have Never Been Modern; Harvard University Press: Cambridge, MA, USA, 1993.

78. Jain, P.; Clancy, G. Preserving Cultural Landscapes: A Cross-Cultural Analysis. In Exploring the Boundaries of Historic Landscape Preservation; Goercheus, C., MacDonald, C., Eds.; Clemson University Digital Press: Clemson, SC, USA, 2008; pp. 15-29.

79. Balée, W. The Research program of historical ecology. Annu. Rev. Anthropol. 2006, 35, 75-98.

80. Rappaport, R.A. Ritual regulation of environmental relations among a New Guinea people. Ethnology 1967, 6, 17-30.

81. Sauer, C.O. The morphology of landscape. Univ. Calif. Publ. Geogr. 1925, 2, 19-53.

82. Jackson, J.E.; Ramírez, M.C. Traditional, transnational, and cosmopolitan: The columbian Yanacona look to the past and to the future. American Ethnologist 2009, 36, 521-544.

83. Li, T.M. Indigeneity, capitalism, and the management of dispossession. Curr. Anthropol. 2010, 51, 385-413.

84. Castaneda, Q. In the Museum of Maya Culture: Touring Chichen Itza; University of Minnesota Press: Minneapolis, MN, USA, 1996.

85. Meskell, L. Human rights and heritage ethics. Anthropol. Q. 2010, 83, 839-860.

86. Parks, S.; McAnany, P.A.; Murata, S. The conservation of Maya cultural heritage: Searching for solutions in a troubled region. J. Field. Archaeol. 2006, 31, 425-432. 
87. McAnany, P.A.; Parks, S. Casualties of heritage distancing: Children, Ch'orti' Indigeneity, and the Copán archaeoscape. Curr. Anthropol. 2012, 53, 80-107.

88. Appadurai, A. The Capacity to Aspire: Culture and the Terms of Recognition. In Culture and Public Action; Rao, V., Walton, M., Eds.; Stanford University Press: Stanford, CA, USA, 2004.

89. Shimada, I.; Schaff, C.B.; Thompson, L.G.; Moseley-Thompson, E. Cultural impacts of severe droughts in the prehistoric Andes: Applications of a 1500-year ice core precipitation record. World Archeol. 1991, 22, 247-270.

90. Long, C.; Smith, A. Cultural Heritage and the Global Environmental Crisis. In Heritage and Globalization; Long, C., Smith, C.B., Eds.; Routledge: New York, NY, USA, 2010; pp. 173-191.

91. Bunten, A.C. Sharing culture or selling out?: Developing the Commodified Persona in the heritage industry. American Ethnologist 2008, 35, 380-395.

92. Greenwood, D. Culture by the Pound: An Anthropological Perspective on Tourism and Cultural Commodification. In Hosts and Guests; Smith, V., Ed.; University of Pennsylvania Press: Philadelphia, PA, USA, 1989.

93. Craik, J. The Culture of Tourism. In Touring Cultures: Transformations of Travel and Theory; Rojeck, C., Urry, J., Eds.; Routledge: London, UK, 1997.

94. Denevan, W. Cultivated Landscapes of Native Amazonia and the Andes; Oxford University Press: Oxford, UK, 2001.

95. Heckenberger, M.J.; Russell, J.C.; Toney, J.R.; Schmidt, M.J. The legacy of cultural landscapes in the Brazilian Amazon: Implications for biodiversity. Phil. Trans. Biol. Sci. 2007, 362, 197-208.

96. Petersen, J.B. Neves, E.G.; Woods, W.I. Gift from the Past: Terra Preta and Prehistoric Amerindian Occupation in Amazonia. In Unknown Amazon: Culture and Nature in Ancient Brazil; McEwan, C., Barreto, C., Neves, E.G., Eds.; British Museum Press: London, UK, 2001; pp. 86-105.

97. Meggers, B.J. Amazonia: Man and Culture in a Counterfeit Paradise; Aldine Publishing Company: Chicago, IL, USA, 1971.

98. Lehman, J.; Kern, D.; Glaser, B.; Woods, W. Amazonian Dark Earths: Origins, Properties, and Management; Kluwer Academic Publishers: Dordrecht, The Netherlands, 2003.

99. Neves, E.G.; Petersen, J.B.; Bartone, R.N.; Silva, C.A. Historical and Socio-Cultural Origins of Amazonian Dark Earths. In Amazonian Dark Earths: Explorations in Space and Time; Lehman, J., Kern, D., Glaser, B., Woods, W., Eds.; Kluwer Academic Publishers: Dordrecht, The Netherlands, 2003; pp. 29-50.

100. Laurance, W.F.; Cochrane, M.A.; Bergen, S.; Fearnside, P.M.; Delamonica, P.; Barber, C.; D’Angelo, S.; Fernandes, T. The future of the Brazilian Amazon. Science 2001, 291, 438-439.

101. Halbert, H.S.; Ball, T.H. The Creek War of 1813-1814; University of Alabama Press: Tuscaloosa, AL, USA, 1995.

102. Wesson, C.B. When Moral Economies and Capitalism Meet. In Across a Great Divide; Scheiber, L.L., Mitchell, M.D., Eds.; University of Arizona Press: Tucson, AZ, USA, 2010; pp. 61-78. 
103. Harjo, S.S. Harjo: Fire Takes the Vulnerable Ones. Indian Country Today, 2 June 2006.

104. Save Hickory Ground Page. Available online: http://www.facebook.com/SaveHickoryGround/ (accessed on 13 December 2012).

105. Chandler, K. Oklahoma Creeks file lawsuit to try to stop Wetumpka Casino. Available online: http://blog.al.com/spotnews/2012/12/oklahoma_creeks_file_lawsuit_t.html_accessed on 13 December 2012).

106. Muscogee (Creek) Nation of Oklahoma Press Release. Available online: https: //www.dropbox.com/ s/724n6lrim3eajpd/MCN\%20Press\%20Release\%20Re\%20Lawsuit.pdf (accessed on 13 December 2012).

107. Indian Burial and Sacred Grounds Watch. Muscogee Burials Threatened by Harrah's Construction. Available online: http://www.ibsgwatch.imagedjinn.com/learn/2002august28.htm/ (accessed on 12 November 2008).

108. Silverman, H. Touring ancient times: The present and presented past in contemporary Peru. Am. Anthropol. 2002, 104, 881-902.

109. Colwell-Chanthaphonh, C.; Ferguson, T.J. Collaboration in Archaeological Practice; Altamira Press: Lanham, MD, USA, 2008.

110. McNiven, I.; Russell, L. Appropriated Pasts: Indigenous Peoples and the Colonial Culture of Archaeology; Altamira: Walnut Creek, CA, USA, 2005.

111. Silliman, S.W. Collaborative Indigenous Archaeology at the Trowel's Edge: Explorations in Methodology, Education, and Ethics; University of Arizona Press: Tucson, AZ, USA, 2008.

112. Maffi, L. Linguistic, cultural and biological diversity. Annu. Rev. Anthropol. 2005, 29, 599-617.

113. Atwood, R. Stealing History; St. Martin's: New York, NY, USA, 2004.

114. Batievsky, J.; Velarde, J. The Protection of Cultural Patrimony in Peru. In Art and Cultural Heritage; Hoffman, B.T., Ed.; Cambridge University Press: New York, NY, USA, 2006; pp. 100-104.

115. Cuno, J. Antiquity Belongs to the World. Chronicle of Higher Education, 4 July 2008.

116. The Art Newspaper. Available online: http://www.theartnewspaper.com/articles/Machu+Picchu+ collection+is+Peru-bound/23368 (accessed on 13 December 2012).

117. In the Air: Art News \& Gossip. Available online: http://blogs.artinfo.com/artintheair/ 2012/11/16/last-of-yales-machu-picchu-artifacts-returned-to-peru-after-years-of-negotiations/ (accessed on 13 December 2012).

(C) 2013 by the authors; licensee MDPI, Basel, Switzerland. This article is an open access article distributed under the terms and conditions of the Creative Commons Attribution license (http://creativecommons.org/licenses/by/3.0/). 